\title{
Testing of high temperature materials within HTR program in Czech Republic
}

\author{
Jan Berka ${ }^{1,2^{*}}$ and Jana Kalivodová ${ }^{1}$ \\ ${ }^{1}$ Research Centre Rez Ltd., Husinec - Řež, Hlavní 130, 25068 Řě̌, Czech Republic \\ ${ }^{2}$ University of Chemistry and Technology Prague, Technická 1905, 16628 Prague 6, Czech Republic
}

Received: 30 April 2015 / Received in final form: 2 October 2015 / Accepted: 25 March 2016 Published online: 27 April 2016

\begin{abstract}
Research institutes and also industrial companies in Czech Republic are involved in High Temperature Gas Cooled Reactor (HTGR) program and activities related to the study of advanced materials and HTGR technologies. These activities are supported by EC (within international projects, e.g. FP7-ARCHER, ALLIANCE, GoFastR can be mentioned) and also by Technology Agency of Czech Republic. Within these activities, degradation of metallic and ceramic materials in the high temperature helium atmosphere is investigated, and also new experimental facilities for material testing are built. As examples of tested materials, Alloy 800 H, ferritic steel P91, austenitic steel 316, Inconel 713 and 738 and corundum ceramics could be named. The selected results of exposure experiments in the high temperature helium environment are presented in this paper.
\end{abstract}

\section{Introduction}

Czech research organizations, universities and industrial companies are involved in High Temperature Reactor (HTR) and also Gas Fast Reactor (GFR) Research program. The examples of these organizations are listed in Table 1. The research used to be supported by the Ministry of Industry and Trade of Czech Republic, presently it is supported by the Technology Agency of Czech Republic. Some of Czech organizations also participate in the international projects aimed to HTR and GFR - as examples the ARCHER [1] and ALLIANCE projects could be named. One of the most important tasks of HTR program is testing and the evaluation of properties and degradation of materials for HTR and other high temperature applications. For these activities, several experimental facilities are used - one of the most significant facility is the High Temperature Helium Loop (HTHL) the scheme of the device is shown in Figure 1. The main operational parameters of the device are: gas pressure 3-7 MPa, temperature in the test section $25-900{ }^{\circ} \mathrm{C}$, gas flow $12-38 \mathrm{~kg} \cdot \mathrm{h}^{-1}$ (for limited time the gas flow could be even lower than the mentioned lower limit). The gas in the loop should consist of helium with only minor impurities $\left(\mathrm{H}_{2}, \mathrm{H}_{2} \mathrm{O}, \mathrm{CO}, \mathrm{CO}_{2}, \mathrm{~N}_{2}, \mathrm{O}_{2}, \mathrm{CH}_{4}\right)$ in concentrations up to approximately $500 \mathrm{vppm}$. See reference [2] for more details

\footnotetext{
* e-mail: jan.berka@cvrez.cz
}

about the device. Another large research infrastructure (and also two new helium loops) is planned to be built in Czech Republic within the SUSEN project [3]. The program of testing the compatibility of metallic alloys with high temperature HTR helium coolant refers to previous activities performed within HTR program in the world (mostly in the last century). Some results are summarized e.g. in references [4-6]. In reference [4], the results from material research within the HTR program in approximately 1960-1990 are summarized, the list of metallic alloys for possible use for HTR components is introduced in this reference. In references [5,6], the high temperature corrosion mechanism of nickel alloys in HTR helium environment is described, the results of corrosion tests of alloys Inconel 617 and Haynes 230 in impure helium at up to $950{ }^{\circ} \mathrm{C}$ are summarized.

\section{Experimental}

The high temperature testing program is focused on corundum and cordierite ceramics and special metallic alloys. The first experiments concerning ceramic materials were aimed at electrical properties at high temperature. Ceramics are usually used as an insulating material for heating elements in experimental devices produced in Research Centre Řž and ÚJV Řě̌. Previously, cordierite ceramics were used for this purpose, but during the test operation of HTHL temperature above ca. $670^{\circ} \mathrm{C}$, it was 
Table 1. List of organizations involved in Czech HTR program.

\begin{tabular}{|c|c|c|}
\hline Name & $\begin{array}{l}\text { Type of } \\
\text { organization }\end{array}$ & Alignment and activities \\
\hline Research Centre Rez Ltd. & Research & $\begin{array}{l}\text { Testing of materials, investigation of technologies, operation of test } \\
\text { facilities }\end{array}$ \\
\hline $\begin{array}{l}\text { University of Chemical } \\
\text { Technology Prague }\end{array}$ & Research & Chemical university, testing, development, experiments \\
\hline MICo & Industry & Developing seals and heat exchangers for nuclear power engineering \\
\hline EVECO & Industry & Gas cleaning technologies \\
\hline ÚJV Řež & $\begin{array}{l}\text { Industry, } \\
\text { engineering }\end{array}$ & Tests and evaluation of material specimens, engineering \\
\hline Prague Casting Services & Industry & $\begin{array}{l}\text { Production of high temperature components by precision castings by the } \\
\text { lost wax method }\end{array}$ \\
\hline $\begin{array}{l}\text { ESTCOM-oxidová } \\
\text { keramika a.s. }\end{array}$ & Industry & Production of high temperature ceramics based on corundum \\
\hline
\end{tabular}

\section{Experimental helium loop HTHL}

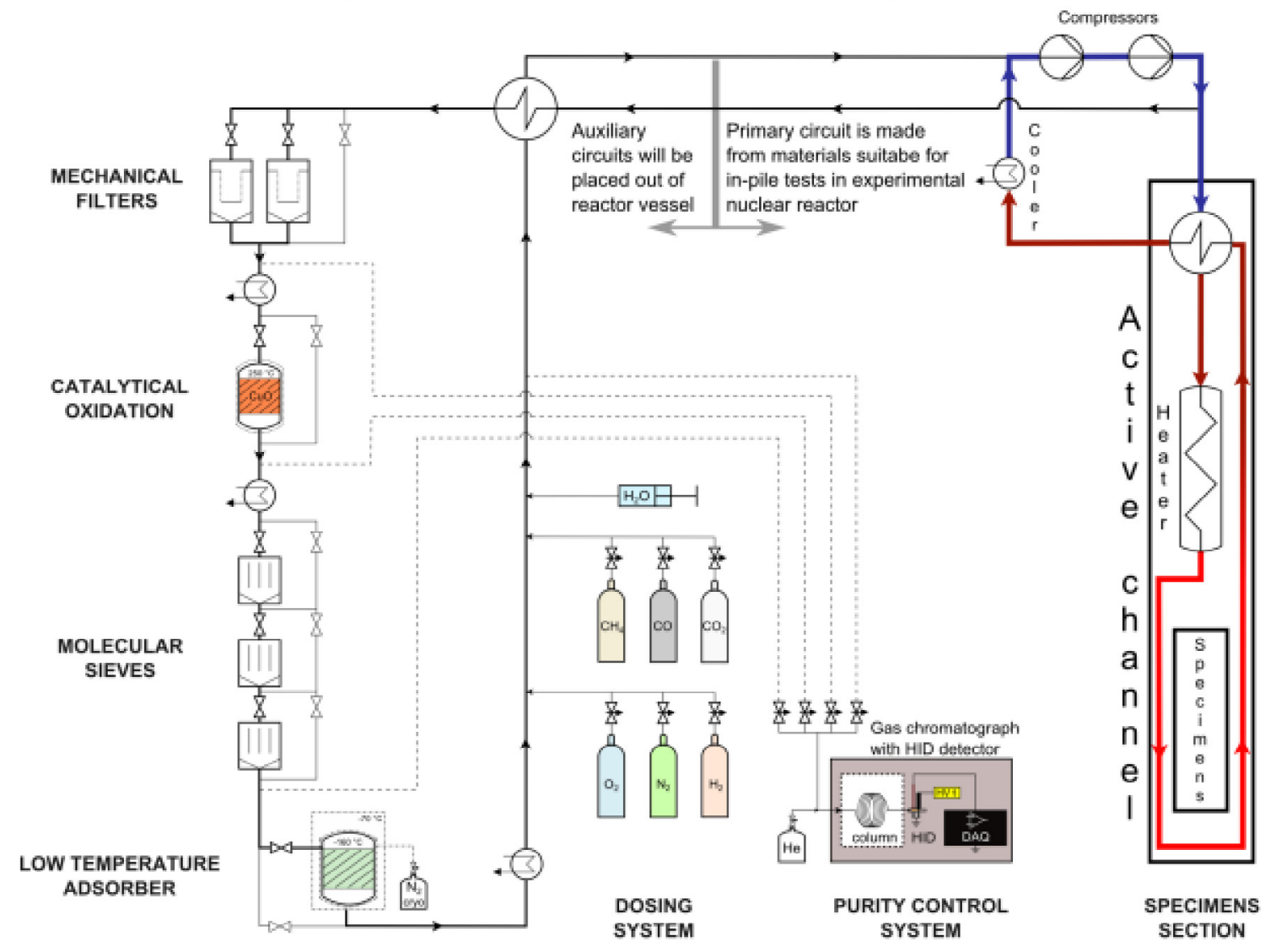

Fig. 1. Scheme of the High Temperature Helium Loop.

not possible to reach the higher temperatures with the heating elements insulated by cordierite ceramics, due to rapid decrease of electrical resistance. When the temperature reached $670{ }^{\circ} \mathrm{C}$, the limit of leakage current given by the standard CSN 331610 - see reference [7] for details - was exceeded. The standard ČSN 331610 gives the upper limit of leakage current $1 \mathrm{~mA}$ per $1 \mathrm{~kW}$ of output for devices with output higher than $3.5 \mathrm{~kW}$. Therefore, the new ceramic insulator for heating elements was developed and its electrical resistance depending on temperature in helium environment tested. See references $[8,9]$ for details about the testing of electrical resistance. For the basic properties of tested ceramic materials, see Table 2. 
Table 2. Basic parameters of tested ceramics.

\begin{tabular}{|c|c|c|c|c|}
\hline Parking according to ČSN EN 60672 & Symbol & Unit & $\begin{array}{l}\text { CORDIERIT } \\
\text { C410 }\end{array}$ & $\begin{array}{l}\text { Corundum ceramics } \\
\text { C799 }\end{array}$ \\
\hline Commercial name & & & TH $7 / 7$ R12 BM & Luxal 203 \\
\hline Porosity & $p_{\mathrm{a}}$ & [\%] & 0.5 & \\
\hline Density & $\rho_{\mathrm{a}}$ & [g.cm $\left.{ }^{-3}\right]$ & 2.1 & $\min .3 .8$ \\
\hline Bending strength & $\sigma$ & {$[\mathrm{MPa}]$} & 60 & $\min .300$ \\
\hline Thermal expansivity coefficient & $\alpha_{30-600}$ & {$\left[10^{-6} \mathrm{~K}^{-1}\right]$} & $2-4$ & $7-8$ \\
\hline $\begin{array}{l}\text { Heat conductivity } \\
\text { Resistance against sudden chase of temperature }\end{array}$ & $\begin{array}{l}\lambda_{30-10} \\
\Delta T\end{array}$ & $\begin{array}{l}{\left[\mathrm{Wm}^{-1} \mathrm{~K}^{-1}\right]} \\
{[\mathrm{K}]}\end{array}$ & $\begin{array}{l}1.2-2.5 \\
250\end{array}$ & $\min .150$ \\
\hline $\begin{array}{l}\text { Relative permittivity } \\
\mathrm{Al}_{2} \mathrm{O}_{3} \text { content }\end{array}$ & $\varepsilon_{\mathrm{r}}$ & $\begin{array}{l}{[-]} \\
\% \\
\text { by weight }\end{array}$ & $\begin{array}{l}5 \\
33\end{array}$ & $\min .99 .5$ \\
\hline Inner electric resistance at 30,200 and $600{ }^{\circ} \mathrm{C}$ & $\begin{array}{l}\rho_{\mathrm{v}, 30} \\
\rho_{\mathrm{v}, 200} \\
\rho_{\mathrm{v}, 600}\end{array}$ & $\begin{array}{l}{[\Omega . \mathrm{m}]} \\
{[\Omega . \mathrm{m}]} \\
{[\Omega . \mathrm{m}]}\end{array}$ & $\begin{array}{l}10^{10} \\
10^{6} \\
10^{3}\end{array}$ & $\begin{array}{l}10^{12} \\
10^{8}\end{array}$ \\
\hline
\end{tabular}

Table 3. Chemical composition of steel 316 L (wt.\%).

\begin{tabular}{llllllllllll}
\hline Element & $\mathrm{C}$ & $\mathrm{Si}$ & $\mathrm{Mn}$ & $\mathrm{P}$ & $\mathrm{S}$ & $\mathrm{Cr}$ & $\mathrm{Mo}$ & $\mathrm{Ni}$ & $\mathrm{Co}$ & $\mathrm{N}$ & $\mathrm{Fe}$ \\
\hline $\begin{array}{l}\text { Min. } \\
\text { Max. }\end{array}$ & & & & & & & 2.00 & 10.00 & & & Bal. \\
\hline
\end{tabular}

Table 4. Chemical composition steel P91 (wt.\%).

\begin{tabular}{lllllllllll}
\hline Element & $\mathrm{C}$ & $\mathrm{S}$ & $\mathrm{Mn}$ & $\mathrm{Si}$ & $\mathrm{P}$ & $\mathrm{Cu}$ & $\mathrm{Ni}$ & $\mathrm{Cr}$ & $\mathrm{Mo}$ & $\mathrm{V}$ \\
\hline & 0.12 & 0.002 & 0.36 & 0.39 & 0.011 & 0.041 & 0.034 & 10.06 & 0.88 & 0.22 \\
\hline Element & $\mathrm{Ti}$ & $\mathrm{W}$ & $\mathrm{Co}$ & $\mathrm{Nb}$ & $\mathrm{As}$ & $\mathrm{Sb}$ & $\mathrm{Sn}$ & $\mathrm{Al}$ & $\mathrm{N}$ & $\mathrm{Fe}$ \\
\hline & 0.007 & $<0.005$ & $<0.003$ & 0.052 & 0.003 & 0.001 & 0.002 & 0.005 & 0.065 & $\mathrm{Bal}$ \\
\hline
\end{tabular}

Table 5. Chemical composition of alloy $800 \mathrm{H}$ (wt.\%).

\begin{tabular}{lllllllllll}
\hline Element & $\mathrm{C}$ & $\mathrm{S}$ & $\mathrm{Cr}$ & $\mathrm{Ni}$ & $\mathrm{Mn}$ & $\mathrm{Si}$ & $\mathrm{Ti}$ & $\mathrm{Nb}$ & $\mathrm{Cu}$ & $\mathrm{Fe}$ \\
\hline & 0.06 & $<0.002$ & 20.5 & 30.5 & 0.7 & 0.50 & 0.34 & 0.01 & 0.10 & $\mathrm{R} 46.7$ \\
\hline Element & $\mathrm{P}$ & $\mathrm{Al}$ & $\mathrm{Co}$ & & & & & & & \\
\hline & 0.010 & 0.28 & 0.1 & & & & & & & \\
\hline
\end{tabular}

Within the test program also, testing of other types of ceramic materials has begun, e.g. investigation of mechanical properties of ceramics Lunit 73 (C610), Luxal 203 (C799), AG 202 (C795) after log-term exposure in high temperature helium environment (up to $900^{\circ} \mathrm{C}$ ) is planned. See reference [10] for details about the materials and their manufacturing.

Also the high temperature metallic alloys were tested during the Czech HTR program: Alloy $800 \mathrm{H}$ (WIG welded by Nicrofer S7020), ferritic steel P91 and austenitic steel $316 \mathrm{~L}$. The chemical composition of tested alloys is listed in Tables 3-5.
The specimens were exposed:

- in the quartz retort in the furnace at $750-760{ }^{\circ} \mathrm{C}$ (the test temperature was determined - among others - with regard of the submission of the projects within which the tests were performed) for up to 1500 hours at atmospheric pressure in the impure helium environment. The chemical composition of inlet helium gas is listed in Table 6 (composition of premixed gas mixture in pressure vessel, concentration of oxygen in the pressure vessel guaranteed by the producer). Concentration of residual moisture was measured by optical hygrometer in the inlet to the retort and ranged from 1-10 vppm; 
Table 6. Chemical composition of premixed gaseous mixture used for experiment.

\begin{tabular}{lll}
\hline Component & $\begin{array}{l}\text { Concentration } \\
{[\text { vppm] }}\end{array}$ & $\begin{array}{l}\text { Partial pressure } \\
{[\mathrm{Pa}]}\end{array}$ \\
\hline $\mathrm{CH}_{4}$ & 100 & 10 \\
$\mathrm{CO}$ & 500 & 50 \\
$\mathrm{H}_{2}$ & 100 & 10 \\
$\mathrm{O}_{2}$ & $<0.1$ & $<0.01$ \\
Helium & Bal. & Bal. \\
\hline
\end{tabular}

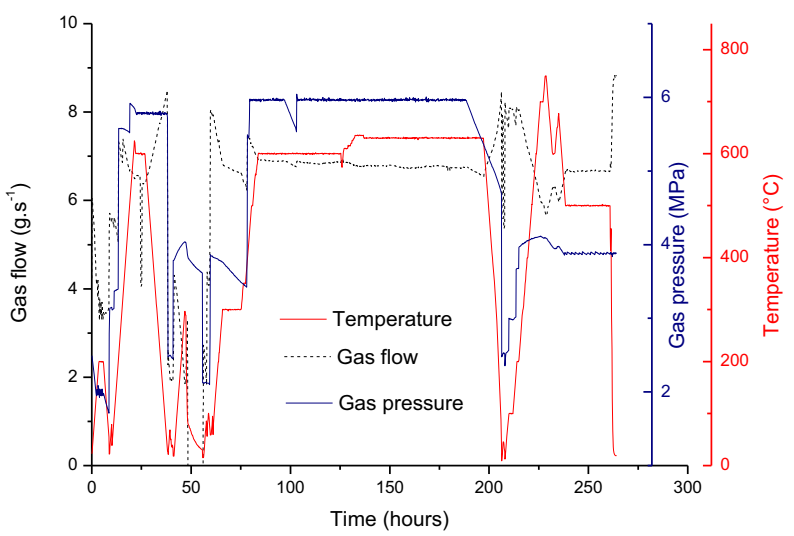

Fig. 2. Parameters during the first period of the test operation of High Temperature Helium Loop.

- in High Temperature Helium Loop (HTHL) during the first period of the test operation of the device. The first period of the test operation lasted 264 hours, HTHL was filled with the pure technical helium (purity 4.6; producer determines that concentration of impurities in this helium contains less than $30 \mathrm{vppm}$ of impurities, and less than 5 vppm of $\mathrm{O}_{2}$ ). The temperature ranged from 25 to $750{ }^{\circ} \mathrm{C}$, the average temperature was $500^{\circ} \mathrm{C}$. Residual moisture content measured by optical hygrometer in helium gas reached max. $250 \mathrm{vppm}$, several check sample analyzed by gas chromatography confirmed the concentration of impurities other than $\mathrm{O}_{2}$ and $\mathrm{H}_{2} \mathrm{O}$ was less than 2 vppm. During this period of the test operation of HTHL separate oximeter was not integrated to the gas circuit. See reference [2] for details about the system of helium purity control of HTHL. The gas pressure and gas flow ranged from 2 to $7 \mathrm{MPa}$ and approximately 2-9 g.s ${ }^{-1} \quad\left(7.2-32.4 \mathrm{~kg} . \mathrm{h}^{-1}\right)$ respectively. The main parameters during this period of the test operation are illustrated in the graph in Figure 2.

After exposure, the degradation of specimens was investigated. Gravimetry, Scanning Electron Microscope (SEM) and theoptical microscope were used for this purpose. The cross-sections of specimens were prepared. The microstructure was further checked by etching by $10 \%$ oxalic acid solution. The change of hardness and micro hardness and fracture toughness (only for P91 and $316 \mathrm{~L}$ ) was also investigated. More details about experiment could be found e.g. in reference [11].

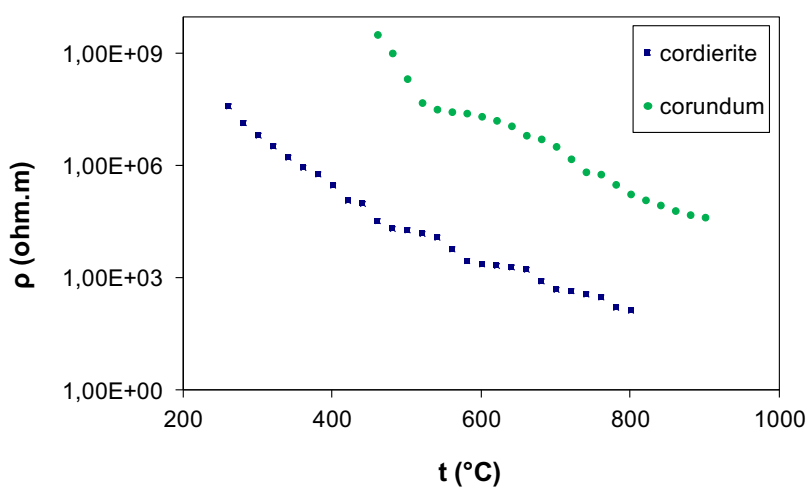

Fig. 3. Dependence of specific electric resistance of tested ceramic materials on temperature.

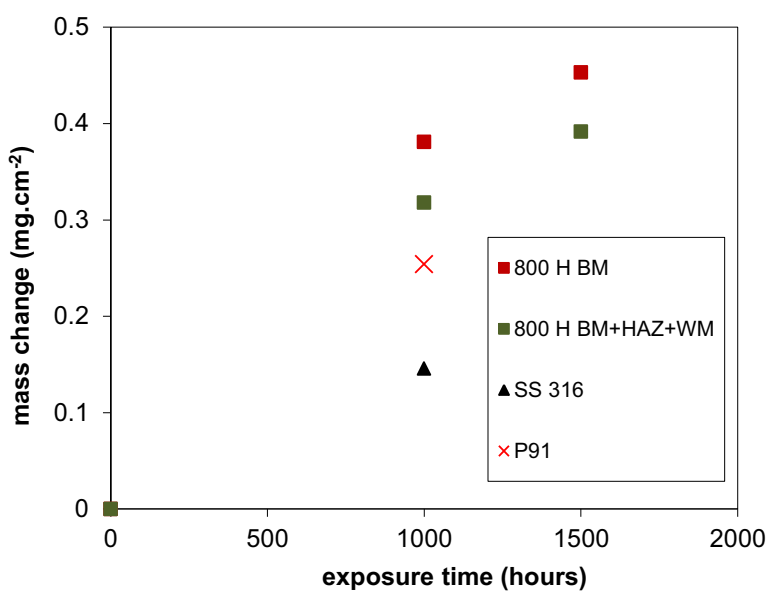

Fig. 4. Mass change of the specimens of alloys exposed in impure helium environment at $750-760^{\circ} \mathrm{C}$. BM: base metal, WM: weld metal, HAZ: heat affected zone.

Tests of other alloys, e.g. Inconel 713, 738 and austenitic steel $\mathrm{N} 155$, at $900^{\circ} \mathrm{C}$ in impure helium environment are also planned. The corrosion test of Alloy $800 \mathrm{H}$, steel P91 and $316 \mathrm{~L}$ in HTHL is in progress.

\section{Selected results}

\subsection{Selected results of tests of ceramics}

The electrical resistivity of corundum ceramics at high temperature (up to $900{ }^{\circ} \mathrm{C}$ ) was proven to be significantly higher than that of cordierite ceramics. The results of the tests are summarized in the graph in Figure 3. The limit of leakage current given by the standard CSN 331610 will not be exceeded even at $900{ }^{\circ} \mathrm{C}$ if corundum ceramics is used for insulating the heating elements. Therefore, corundum ceramics C799 is convenient for this purpose.

\subsection{Selected results of tests of metallic alloys}

The mass changes of the specimens of alloys exposed in the furnace are summarized in the graph in Figure 4. 


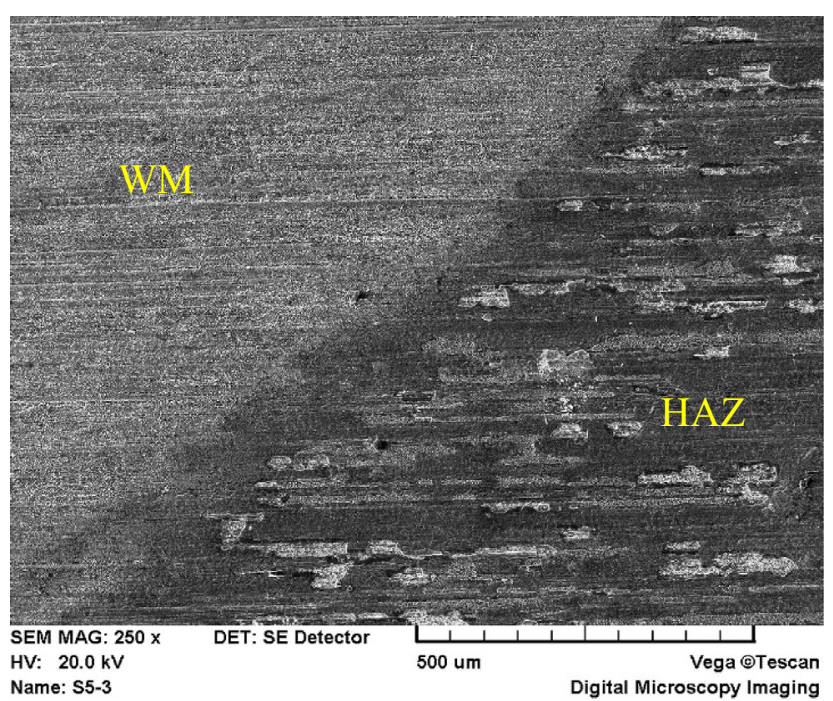

Fig. 5. Spalling of surface layer on welded specimen of Alloy $800 \mathrm{H}$ after exposure of 1500 hours at $760{ }^{\circ} \mathrm{C}$ in impure helium.

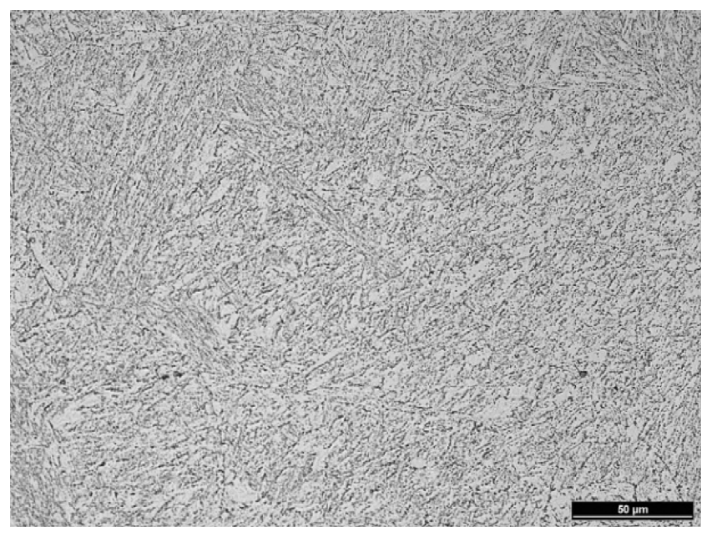

a

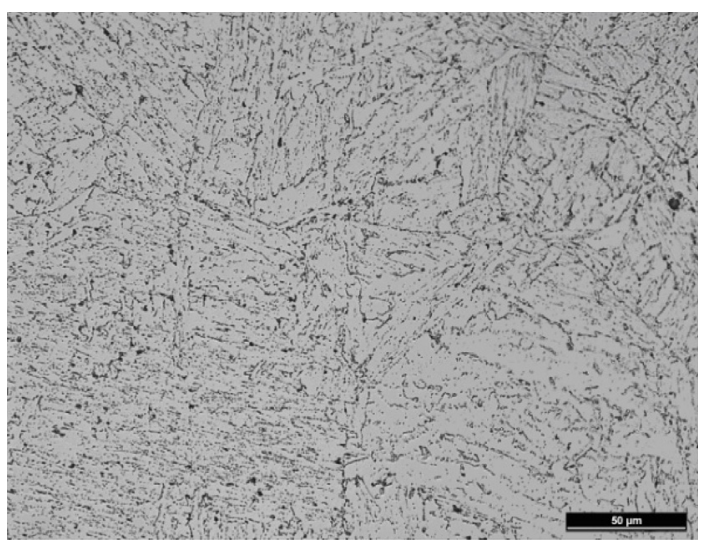

b

Fig. 6. Microstructure of steel P91 (the cross-section of the specimen): (a) in as-received state, (b) after exposure in impure helium $750{ }^{\circ} \mathrm{C} / 1000 \mathrm{~h}$.

The uncertainty of the results could be estimated to be about $10 \%$. The mass gain of alloy $800 \mathrm{H}$ was the highest of that of tested alloys.

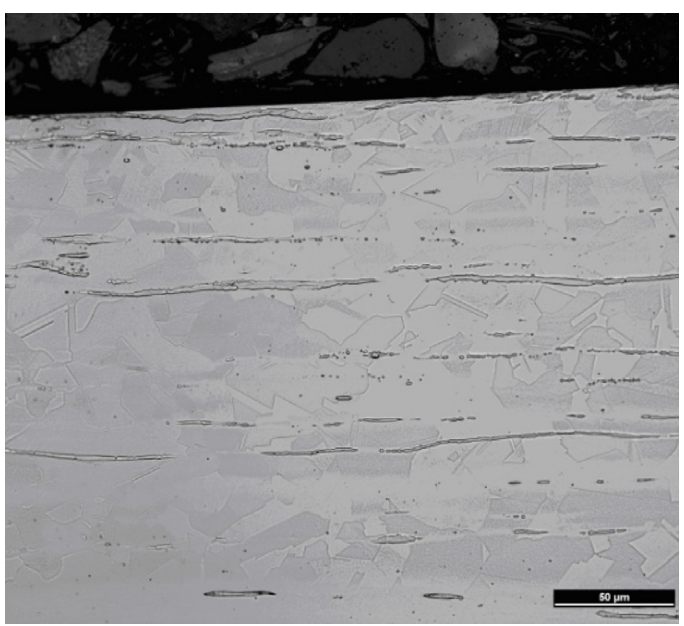

a

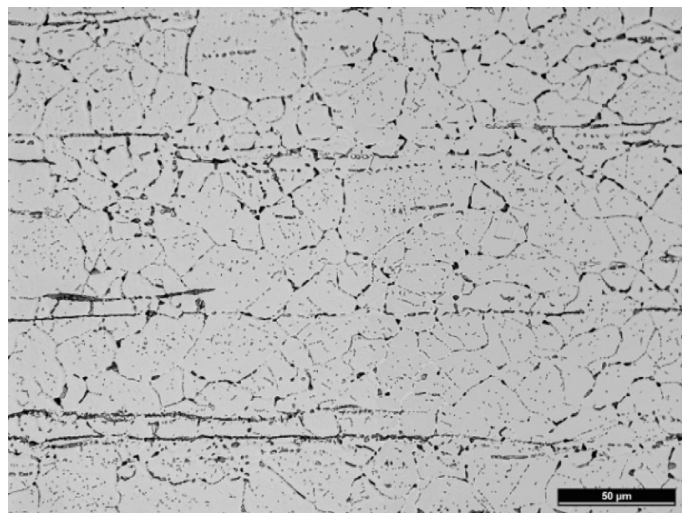

b

Fig. 7. Microstructure of steel $316 \mathrm{~L}$ (the cross-section of the specimen): (a) in as-received state, (b) after exposure in $\mathrm{He}$ $750{ }^{\circ} \mathrm{C} / 1000 \mathrm{~h}$.

The oxidation layer on the surface of exposed specimens was mainly formed by chromium and manganese oxides. The spalling of the oxide layer was observed mainly on the surface of the Heat Affected Zone (HAZ) obviously visible on Figure 5. Thickness of the oxide layer on all tested metallic specimens was in the range 2-4 microns.

The images of microstructure of steels P91 and $316 \mathrm{~L}$ before and after exposure are shown in Figure 6 and Figure 7 respectively. Precipitation of particles (carbides) after exposure is apparent (see Figs. 6b and $7 \mathrm{~b}$ ). In case of P91, the subsurface layer without carbides (up to ca. $17 \mu \mathrm{m}$ thick) appeared after exposure. The microstructure of base metal and weld join of Alloy $800 \mathrm{H}$ before and after exposure is given in Figures 8 and 9. The precipitation of particles after exposure is visible by comparison of these figures. After exposure of 1000 hours, significant precipitation of particles $\left(\mathrm{M}_{23} \mathrm{C}_{6}\right.$ and $\left.\gamma\right)$ was noticed. Under the corrosive layer $\sim 20 \mu \mathrm{m}$ undersurface layer without precipitates was observed. There are some differences in composition of the surface corrosive layer after exposure in the furnace and in HTHL during the test operation - except chromium although a significant percentage of iron and nickel was detected by SEM 


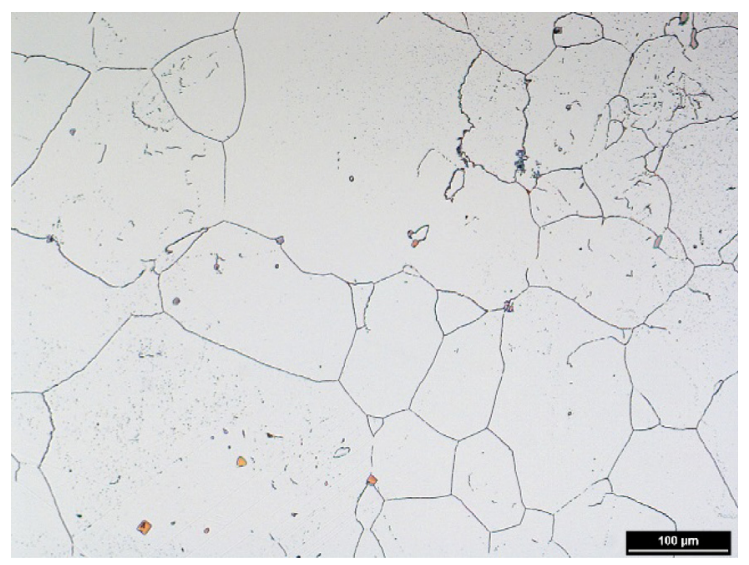

a

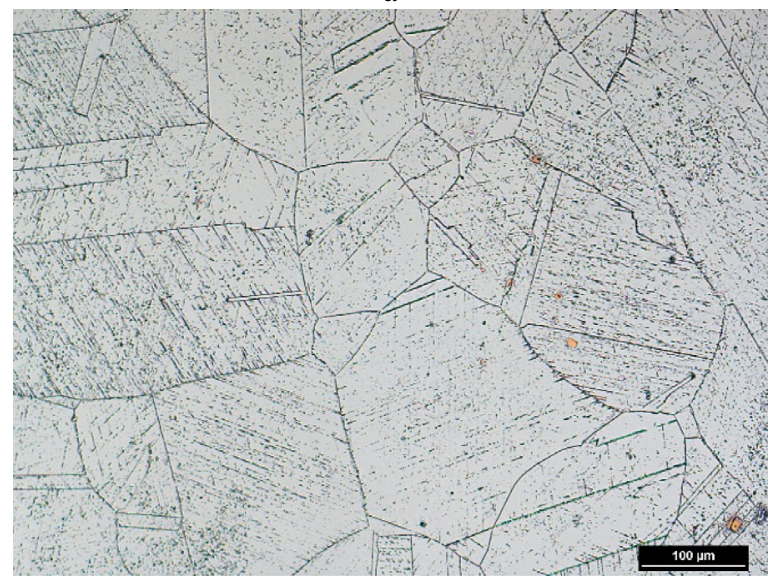

b

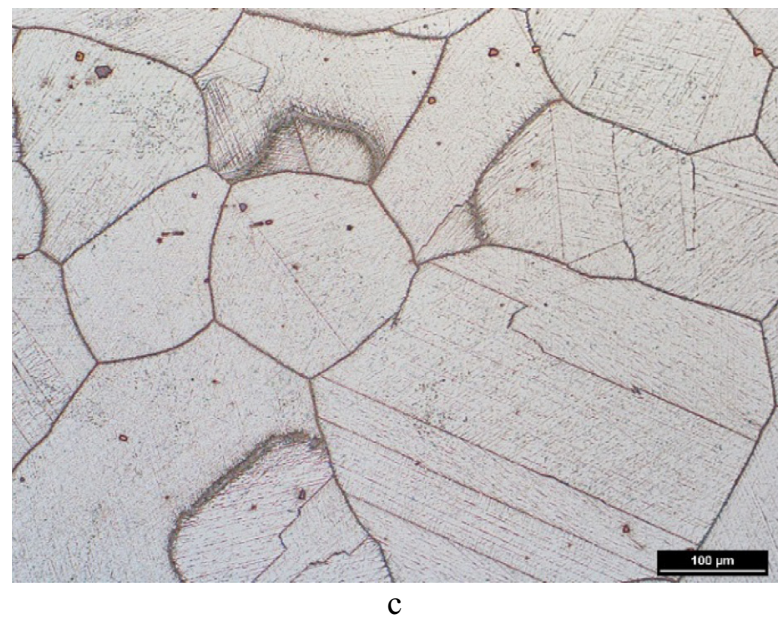

Fig. 8. Microstructure of base metal of Alloy $800 \mathrm{H}$ on the crosssection of specimens: (a) in as-received state, (b) after exposure of 1500 hours in impure helium at $760{ }^{\circ} \mathrm{C}$ in the furnace, (c) after exposure in HTHL during 264 hours of the test operation.

analysis in the surface corrosive layer on Alloy $800 \mathrm{H}$ after exposure in HTHL. Mass gain of specimen after exposure in HTHL was $0.06 \mathrm{mg} . \mathrm{cm}^{-2}$. The dependence of hardness and micro hardness of tested materials on exposure time is illustrated in Figure 10.

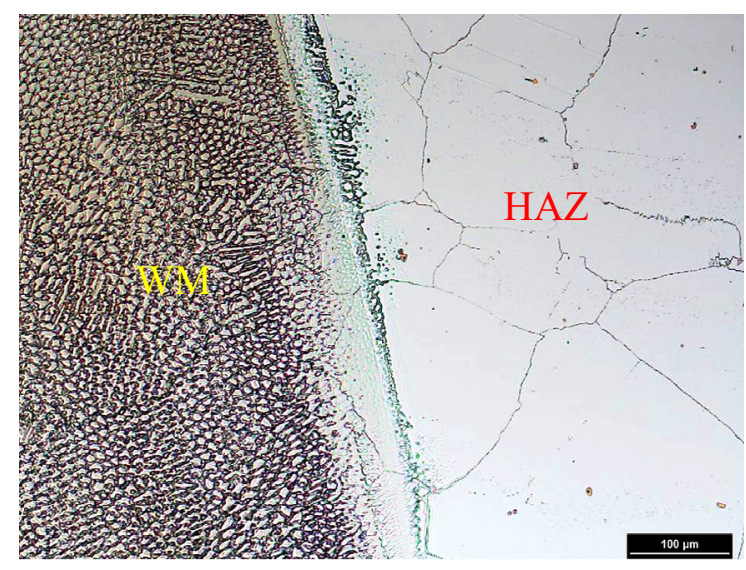

a

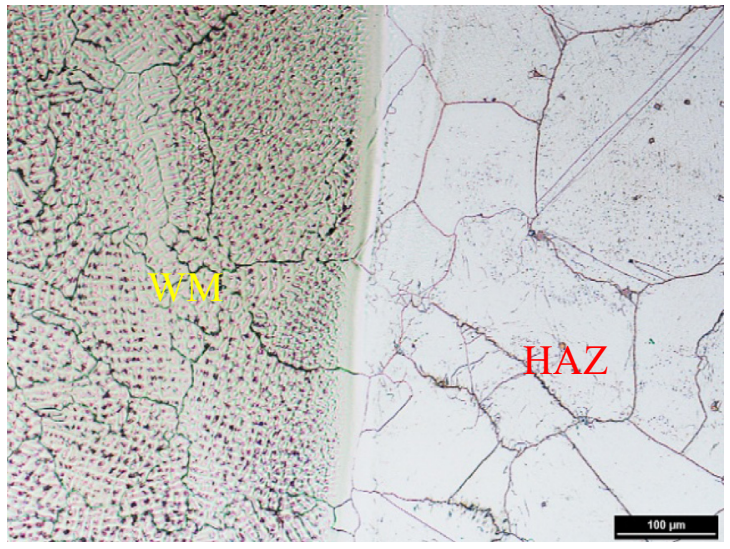

b

Fig. 9. Microstructure of interface of weld metal and heat affected zone of alloy $800 \mathrm{H}$ : (a) in as-received state, (b) after exposure of 1500 hours in impure helium at $760{ }^{\circ} \mathrm{C}$.

The fracture toughness of austenitic steel $316 \mathrm{~L}$ decreased after exposure of 1000 hours at $750{ }^{\circ} \mathrm{C}$ in impure helium of $67 \%$ (from value of $\mathrm{J}_{0.2}$ integral $62 \mathrm{J.cm}^{-2}$ in as-

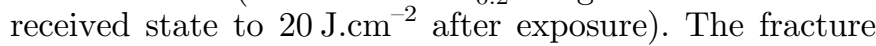
toughness of ferritic steel P91 almost did not change after exposure. The change of fracture toughness of $316 \mathrm{~L}$ is probably caused by changes of material at high temperature independently of environment (e.g. due to the precipitation of the sigma phase after annealing at $750^{\circ} \mathrm{C}$ during $1000 \mathrm{~h}$ ) - however, to prove this assumption, other tests in different environments (e.g. in air) at the same temperature are needed.

\section{Conclusions}

The research organizations and industrial companies in Czech Republic participate in the research and development of materials and technologies for High Temperature gas cooled Reactors and other high temperature industrial applications. These activities are supported - among others - by the European Commission within the international FP7 projects and also by the Technology Agency of Czech Republic. The infrastructure for this investigation 


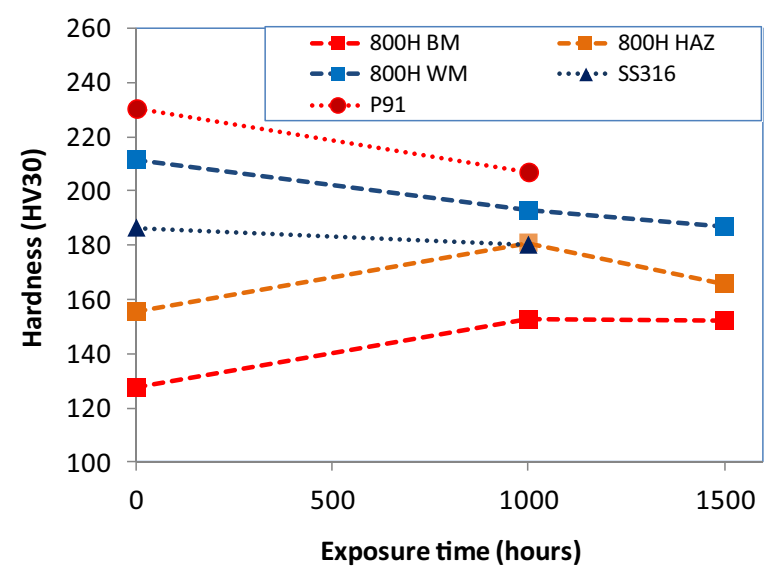

a

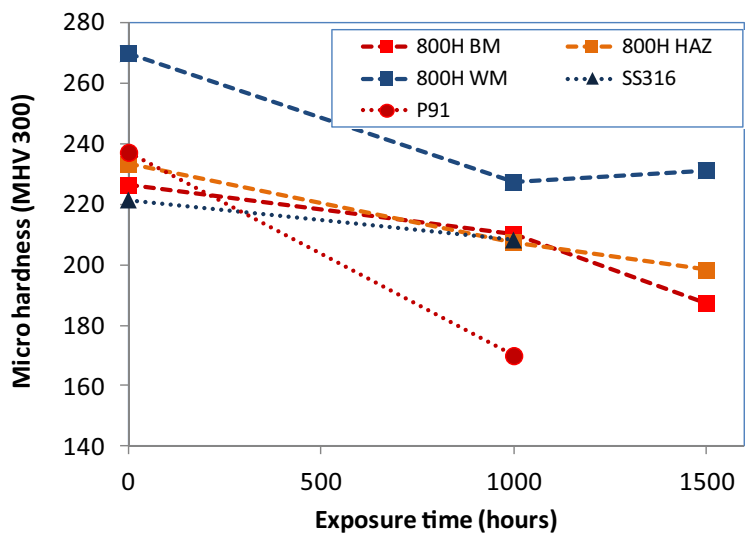

b

Fig. 10. (a) hardness, (b) micro hardness of tested alloys depending on exposure time in impure helium at $750-760{ }^{\circ} \mathrm{C}$.

exists in Czech Republic and is being extended. Some results of investigation of high temperature degradation of metallic and non-metallic materials are already available, other tests and evaluation are still in progress and others are planned.

With regard to metallic materials which were tested so far: stainless steel $316 \mathrm{~L}$ proved the best corrosion resistance in impure helium at $750-760{ }^{\circ} \mathrm{C}$, however mechanical properties of this steel changed after exposure at high temperature. Fracture toughness of steel P91 almost did not change after exposure at high temperature. These materials are not designed for long-term operations at such high temperatures; however these materials could be used e.g. for not mechanically loaded parts of experimental devices (for example sample holders) or colder parts. Mechanical properties of Alloy $800 \mathrm{H}$ after exposure at high temperature were not tested. According to obtained results, corrosion resistance of Alloy $800 \mathrm{H}$ at high temperature in impure helium seems to be worse compared to other tested materials.

With regards to tested ceramic materials, corundum base ceramics seems to be a better material as an insulator of heating elements for high temperatures than commonly used cordierite ceramics.

The presented work was financially supported by the TACR (Alfa Project TA03010849 and TA03020850) and by the SUSEN Project CZ.1.05/2.1.00/03.0108 realized in the framework of the European Regional Development Fund (ERDF).

The presented work was also supported within the FP7-ARCHER project supported by the European Commission.

The authors also thank colleagues from ÚJV Rež and Institute of Plasma Physics of the Academy of Sciences of the Czech Republic for performing and evaluating some tests on exposed specimens.

\section{References}

1. http://archer-project.eu/, cited on 01/07/2014

2. J. Berka, J. Matěcha, M. Černý, I. Víden, F. Sus, P. Hájek, New experimental device for VHTR structural material testing and helium coolant chemistry investigation - High Temperature Helium Loop in NRI Rež, Nucl. Eng. Des. 251, $203(2012)$

3. http://susen2020.cz/, cited on 01/07/2014

4. K. Natesan, A. Purohit, S.W. Tam, Report NUREG/CR6824: Materials Behavior in HTGR Environments, Office of Nuclear Regulatory Research, Washington, 2003

5. C. Cabet, A. Terlain, A. Girardin, D. Kaczorowski, M. Blat, J. L. Séran, S. Dubiez Le Golf, Benchmark CEA - AREVA NP EDF of the Corrosion Facilities for VHTR, in Proceedings of ICAPP 2007, Nice, France, May 13-18, 2007 (2007), Paper 7192

6. C. Cabet, F. Rouillard, Corrosion of high temperature metallic materials in VHTR, J. Nucl. Mater. 392, 235 (2009)

7. http://nahledy.normy.biz/nahled.php?i=71705J

8. J. Berka, A. Rotek, J. Vit, J. Kutzendorfer, Testing of ceramics for production of heating elements for usage in High Temperature Helium Loop, in Proceedings of the 22th International Conference on Nuclear Engineering ICONE22, Prague, Czech Republic, July 7-11, 2014 (2014), paper No. ICONE22-31019

9. J. Berka, A. Rotek, J. Vít, Testing of electric properties of ceramic components for thermally stressed parts of High Temperature Helium Loop, Paliva 5, 123 (2013)

10. http://www.estcom.cz/data/soubory/slozeni-vlastnosti-hmot. pdf, cited on $28 / 12 / 2014$

11. J. Berka, J. Kalivodova, M. Vilemova, Z. Skoumalova, P. Brabec, Corrosion tests of high temperature alloys in impure helium, in Proceedings of the HTR 2014, Weihai, China, October 27-31, 2014 (2014), Paper HTR2014-41235

Cite this article as: Jan Berka, Jana Kalivodová, Testing of high temperature materials within HTR program in Czech Republic, EPJ Nuclear Sci. Technol. 2, 24 (2016) 